
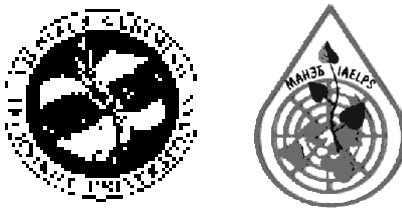

JOURNAL OF ENVIRONMENTAL ENGINEERING

AND LANDSCAPE MANAGEMENT

http:/www.vtu.lt/english/editions

2004, Vol XII, No 1, 12-21

\title{
UTILIZATION OF BOON AND CHAFF FOR MANUFACTURING LIGHTWEIGHT WALLING MATERIALS
}

\author{
Algimantas Kazragis ${ }^{1}$, Aušra Juknevičiūtè², Albinas Gailius ${ }^{3}$, Elena Zalieckienė ${ }^{4}$ \\ 1, 2, 4 Dept of Chemistry and Bioengineering, Vilnius Gedimas Technical University, \\ Sauletekio al. 11, LT-10223 Vilnius-40, Lithuania \\ 3 Dept of Building Materials, Vilnius Gediminas Technical University, \\ Sauletekio al. 11, LT-10223 Vilnius-40, Lithuania \\ E-mail:1'chemkat@fm.vtu.lt; ${ }^{2}$ aujuk@fm.vtu.lt; ${ }^{3}$ albinas@st.vtu.lt, ${ }^{4}$ elenaz@fm.vtu.lt
}

Received 20 May 2003; accepted 17 Oct 2003

\begin{abstract}
Lightweight composites for walls and thermal insulation, containing anhydrite (An) or aluminate cement (Al), vinyl acetate (VA) or cellulose $(\mathrm{Cl})$ polymeric binders and cellulose fiber fillers (boon, chaff) were produced. The best results were obtained for transportation and construction of items containing: An $\geq 30-45 \%, \mathrm{Al} \geq 30-50 \%$, VA $\geq 1-5 \%$, $\mathrm{Cl} \geq 0,5-5,0 \%$, boon or chaff $\geq 40-47 \%$. Polymeric binder VA for both kinds of cement is better than $\mathrm{Cl}$. An is better for boon than for chaff. Aluminate cement is a good binder for both types of fiber fillers. Density $\mathrm{r}$ of a composite containing cements $50-60 \%$ is less than $400 \mathrm{~kg} / \mathrm{m}^{3}$. According to density such composite materials are light-weight heat-insulating materials. Density $\left(\rho \leq \mathrm{kg} / \mathrm{m}^{3}\right)$ depends on the amount of cement content. Bending strength for samples with $\rho \leq 400 \mathrm{~kg} / \mathrm{m}^{3}$, containing CMC is $0,6-1,3 \mathrm{MPa}$. Coefficient of thermal conductivity for samples, density with $400 \mathrm{~kg} / \mathrm{m}^{3}$ is $0,06 \mathrm{~W} / \mathrm{m} \cdot \mathrm{K}$.
\end{abstract}

Keywords: utilization, lightweight walling materials, thermal insulation, boon, chaff, inorganic binders and polymeric binders.

\section{Introduction}

One of the major environmental problems facing the world today is reduction of the greenhouse effect. Lithuania signed the Vienna Convention pledging the countries to take all possible actions against the depletion of the ozone layer surrounding the Earth which is caused by the greenhouse effect. One of possible ways to achieve this is to utilize organic waste in the manufacture of various materials instead of burning or rotting them.

Two large groups of materials-construction and lightweight wall materials are among the great variety of known building materials.

Lightweight wall materials are also thermal insulating materials. These are composites heat insulating properties of which are determined by their macro structure which includes bubbles of air. The most effective materials of this type are fibrous composites and foam plastics.

The costs of most wall materials are rather high due to large energy expenditures and significant custom duties in Lithuania. On the other hand, wall materials based on local materials are practically absent. That is why it is expedient to start to manufacture lightweight wall and thermal insulating materials which require small amounts of energy and use of local agricultural production waste materials. These materials could be manufactured directly at a building or renovation site what is very important when such a work is undertaken in rural areas. Also, such a production could reduce $\mathrm{CO}_{2}$ and $\mathrm{CH}_{4}$ emissions, if agricultural production waste is not burnt or decayed. This could contribute, maybe at a less extent, to lowering the world greenhouse effect.

The present investigation is based on the experience gained by the authors in using agricultural waste, such as cellulose fibres and particular kinds of plants in the production of heat- and sound-insulating materials from straw and PVA [1-4], straw and CMC, straw, cane and various polymer fillers [5-7] as well as on the experiments conducted. In addition, use was made of the data published by the researchers from various countries on using cellulose-containing waste to increase the strength of sewer pipes [8] as well as investigation of the effect of cellulose fibres on wood fibre-cement com- 
posites [9], the properties of mortars with straw and wheat [10], the temperature effect on wood fibre cement composites [11], the effect of admixtures on cellulosecement articles [12], the use of rice processing waste in the manufacture of building products $[13,14]$, Brazil fibres effect on cement composites [15], lignosulphonate admixture effect on cement hydration $[16,17]$ and the addition of bamboo fibres to cement paste [18].

\section{Investigation object}

In agricultural production considerable amounts of cellulose-containing waste - boon and chaff can be found.

Boon is a hardened part of a flax stem remaining in flax processing when fibres are separated from the sticks. It makes about $65-75 \%$ of the flax stem mass. Boon also contains 50-64\% cellulose and 21-29\% lignine.

In some areas, for example, in Dotnuva, where a house is built with walls made of $75 \%$ of clay, $20 \%$ of boon and 2-5\% of sand, boon is used to produce cellulose, paper and building panels. The Institute of Thermal Insulation recommends to manufacture non-fired fibre bricks of clay (even with admixture of limestone) with addition of 40-60\% boon, sawdust and chopped straw [19].

In the present tests boon obtained from $\mathrm{AB}$,Ukmergès linai“ (Ukmergè Flax) was used.

Chaff consists of wheat waste containing grains, chopped leaves of cereals and straw, weed seeds, etc. Chaff may be used as an organic filler of heat-insulating materials.

Chaff for testing was obtained from Vilnius Granary.

\section{Testing materials}

In manufacturing lightweight materials with boon or chaff for wall panels, the following materials were used as binders.

Inorganic binders

- Anhydrite cement - made by „Palemonas ceramics“, Co, volume $(25,6-33,5) \% \mathrm{CaO}$ and $(27,4-41,0) \%$ $\mathrm{SO}_{3}$; initial setting tome $(0,5-2,5) \mathrm{h}$, final setting time (2-4) h, strength gained in 28 days: flexural strength (2,6-3,0) $\mathrm{MPa}$, compression strength (16-18) $\mathrm{MPa}$. $\mathrm{X}$-ray phase analysis has shown that $\mathrm{CaSO}_{4}$ prevails in the material.

- Aluminate cements Gorkal 40 (G-40) and Gorkal 70 (G-70) - from „Gorkal“ Co (Trzebinia, Poland), containing (69-72) \% $\mathrm{Al}_{2} \mathrm{O}_{3}$ and (28-29) \% CaO; initial setting time $\geq 40 \mathrm{~min}$, final setting time $\leq 8 \mathrm{~h}$; strength gained after $24 \mathrm{~h}$ : flexural - (6-8) MPa, compression (30-40) $\mathrm{MPa}$. X-ray analysis has shown that the material mainly consists of $\mathrm{CaO} \cdot \mathrm{Al}_{2} \mathrm{O}_{3}, \mathrm{CaO} \cdot 2 \mathrm{Al}_{2} \mathrm{O}_{3}$, $12 \mathrm{CaO} \cdot 7 \mathrm{Al}_{2} \mathrm{O}_{3}$ and $\alpha-\mathrm{Al}_{2} \mathrm{O}_{3}$.

\section{Polymer binders}

- Polyvinylacetate (PVA)-HW1 trademark commercial dispersion (Finland) containing $50 \%$ dry solids; it is an aqueous dispersion $1: 1$.

- PVA powder-Vinnap RS55Z trademarks commercial product; $4 \%$ dispersion.

- Carboximethylcellulose (CMC) powder-commercial product (Finland); $4 \%$ dispersion.

- Walocell-commercial CMC product MK 3000 supplied in the form of powder; $4 \%$ dispersion.

- Methylcellulose (MC) - „Metylan normal“ produced in Germany; $2 \%$ dispersion.

Antiseptic additives used were sodium hexafluorosilikate $\mathrm{Na}_{2}\left[\mathrm{SiF}_{6}\right]$ as well as fire retardant - sodium tetraborate $\mathrm{Na}_{2} \mathrm{~B}_{4} \mathrm{O}_{7} \cdot 10 \mathrm{H}_{2} \mathrm{O}$.

\section{Testing methods}

The work was carried out according to the following scheme: product composition design - manufacture of specimens - determination of specimen properties: durability - density - strength, specific thermal conductivity - thermal resistance - economic calculations - conclusions, recommendations.

Shape holding (steadfastness) of specimens was assessed in the following way: a specimen cured for 3 days in the laboratory at $20{ }^{\circ} \mathrm{C}$ is laid a the table and a steel plate of $160 \times 40 \times 3 \mathrm{~mm}$ is placed over it. Then, a load is applied to the plate and the initial time of specimen failure is fixed: 1) an applied load is $200 \mathrm{~g}$ - if the failure of the specimen occurs, $\mathrm{O}$ points are scored; 2) if the failure does not occur, the load is increased up to $500 \mathrm{~g}$ - if the failure occurs, 1 point is scored; 3) a load of $200 \mathrm{~g}$ is added to $500 \mathrm{~g} \mathrm{load} \mathrm{-} \mathrm{if}$ the specimen fails, 2 points are scored, if not -3 points are given.

The density, flexural and compression strength, specific thermal conductivity and $\mathrm{pH}$ of specimens were found by standard procedures. Using a derivatograph Q-1500 for analysing 5 specimens at a time performed thermographic testing. X-ray photographs were obtained by a diffractometer DRON-2 (Russia) (Co anode, Fe filter, slits $-1: 2: 0,5 \mathrm{~mm})$; diffractometer tube's operating mode: $U=3 \mathrm{kV}, I=10 \mathrm{~mA}$.

\section{Results and discussion}

\subsection{The effect of inorganic filler composition on the properties of composites}

- Composites containing anhydrite cement

A thermographic analysis of a hardened and cured specimen containing $50 \%$ of anhydrite cement, $45 \%$ of boon and $5 \%$ of CMC (dry solids) was made with the main part of fibre filler removed by screening it through a $0,2 \mathrm{~mm}$ sieve.

Analysing the temperature curve presented in a thermograph (Fig 1), which demonstrates the specimen's 


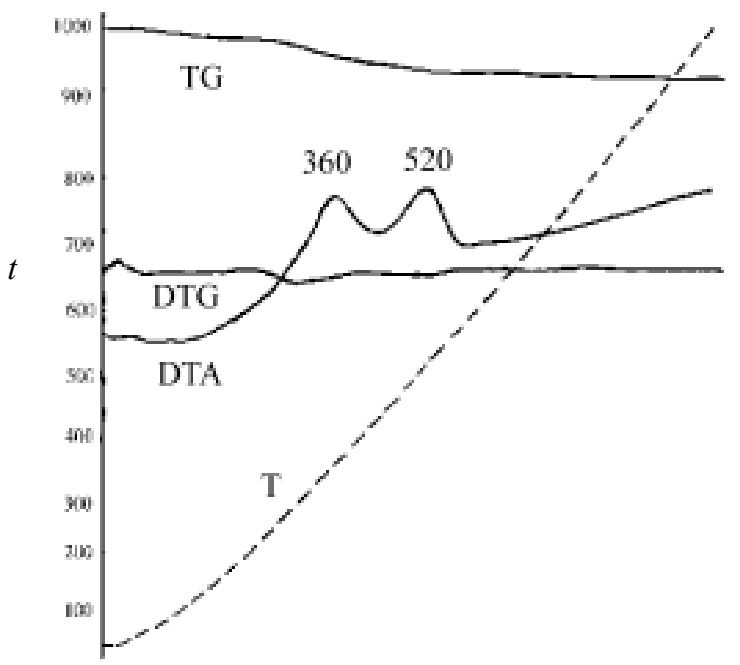

Fig 1. Derivatogram of mineral particles present in a specimen containing anhydrite cement, boon and CMC during heating. Temperature curve $(\mathrm{T})-10 \%$ min, mass change curve (TG) $-200 \mathrm{mg}$, heat change curve (DTA) $-250 \eta \mathrm{m}$, mass change rate curve (DTG) $-500 \eta \mathrm{m}$

thermal behavior (DTA) at heating, one can observe a considerable exothermic effect reaching the maximum at a temperature of $360{ }^{\circ} \mathrm{C}$ and $520{ }^{\circ} \mathrm{C}$. It is associated with the splitting of $\mathrm{CMC}$ which softens at $170{ }^{\circ} \mathrm{C}$ and splits and burns at a higher temperature; the boon also burns up when heated. The fact that the process is completed at a temperature exceeding $520{ }^{\circ} \mathrm{C}$ is evident from the curves representing mass transformation (TG) and the rate of mass transformation (DTG).

$\mathrm{X}$-ray analysis of a hardened and cured specimen, containing the above-mentioned amounts of anhydrite cement and other components and from which the main part of fibre filler was removed, was made.

As can be seen from the roentgenogram (Fig 2), major components of a mineral composition of the specimen are anhydrite and quartz (to a much lower degree). Other admixtures are represented in small quantities not allowing for their identification.

The fact that thermodynamically feasible compounds $\left(\mathrm{CaSO}_{4} \cdot 0,5 \mathrm{H}_{2} \mathrm{O}, \mathrm{CaSO}_{4} \cdot 2 \mathrm{H}_{2} \mathrm{O}\right)$ are not formed in large amounts may be accounted for low hydration degree of $\mathrm{CaSO}_{4}$ found in anhydrite cement and a short-time interaction of $\mathrm{CaSO}_{4}$ of the specimen with water during its preparation, which prevented $\mathrm{CaSO}_{4}$ hydration in a heterogenic system $-\mathrm{CaSO}_{4}$ and $\mathrm{H}_{2} \mathrm{O}$.

- Compositions with aluminate cement

A thermographic analysis of a hardened and cured specimen containing $61 \%$ of aluminate cement G-70, $18 \%$ of chaff and $21 \%$ of PVA (dry solids) with a portion of fibre filler removed by screening through $0,2 \mathrm{~mm}$ sieve, was made.

The curves of the thermogram (Fig 3) show that absorption water evaporates at about $120{ }^{\circ} \mathrm{C}$, while at $170{ }^{\circ} \mathrm{C}$ destruction of PVA takes place and at $300{ }^{\circ} \mathrm{C}$, $340{ }^{\circ} \mathrm{C}$ and $380{ }^{\circ} \mathrm{C}$ dehydration (endothermal effects and mass decrease) of the products may be observed. However, in the temperature interval of $300{ }^{\circ} \mathrm{C}-700{ }^{\circ} \mathrm{C}$ the burning up of organic materials takes place, reaching the maximum at $460{ }^{\circ} \mathrm{C}$ (as can be seen on the DTA curve representing exothermal effect). At a temperature of about $600{ }^{\circ} \mathrm{C}$ smoldering rather than burning can be observed.
Fig 2. X-ray-gram of mineral materials present in a specimen containing anhydrite cement, boon and CMC. Type of X-ray apparatus-DRON-2, anode-Co, filter-Fe, A-anhydrite, Q-quartz

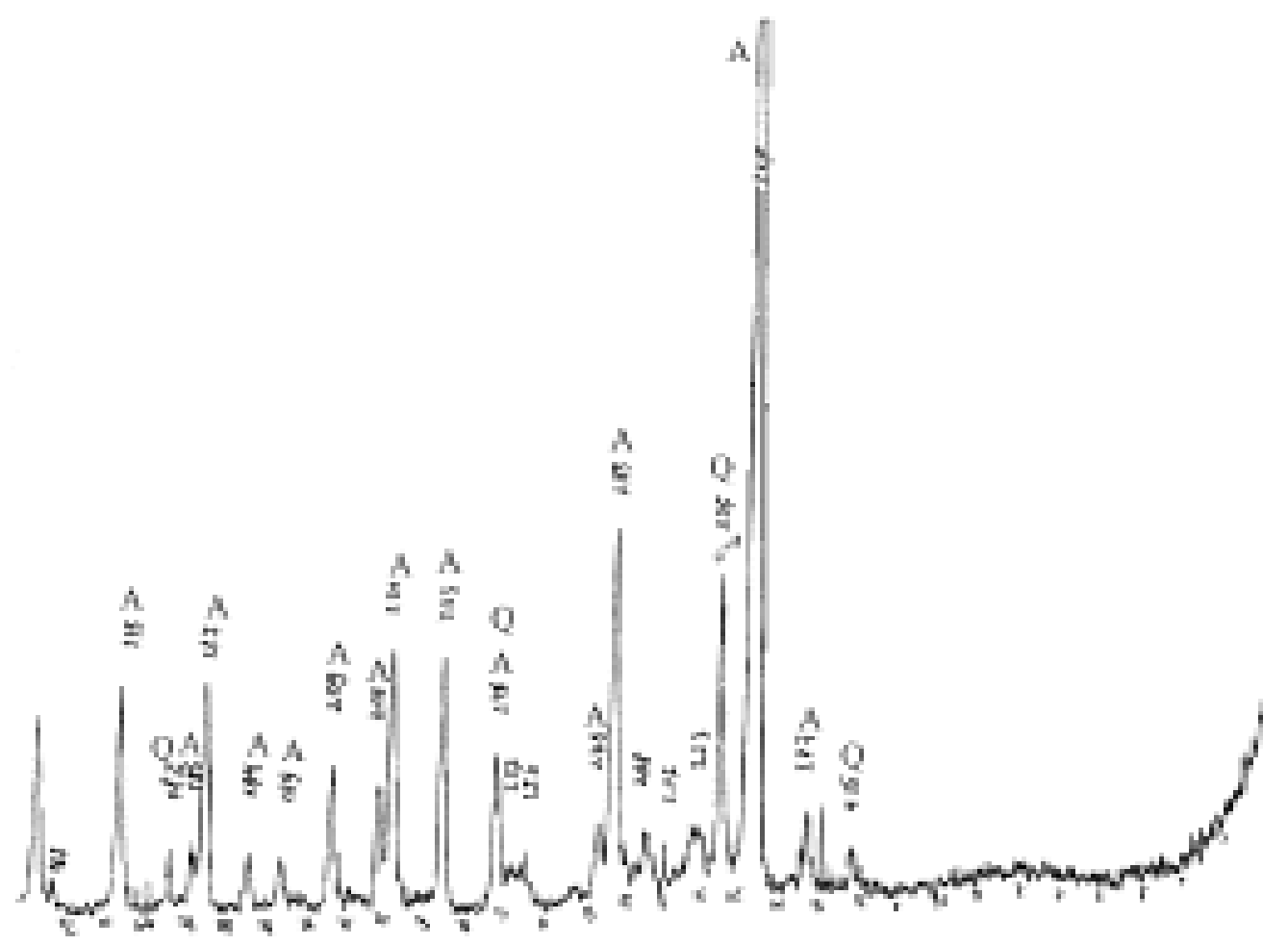


At $860{ }^{\circ} \mathrm{C}$ carbonates decompose (DTG curve), while at $960{ }^{\circ} \mathrm{C}-\mathrm{CA}$ crystallization takes place. X-ray phase analysis was made of a hardened and cured specimen containing aluminate cement and other composites in the considered amounts and from which the main portion of the fibre filler was removed. One can see on the roentgenogram (Fig 4) that major mineral components of the specimen are $\mathrm{CAH}_{10}, \mathrm{AH}_{3}$ (gibbsite), $\alpha-$ $\mathrm{Al}_{2} \mathrm{O}_{3}$ (corundum) as well as calcite and vaterite (both $\mathrm{CaCO}_{3}$ ).

The CA hydratation takes place as follows:

$$
\mathrm{CA} \stackrel{\mathrm{H}_{2} \mathrm{O}}{\longrightarrow} \mathrm{CAH}_{10} \rightarrow\left|\begin{array}{c}
\mathrm{C}_{2} \mathrm{AH}_{8} \\
\mathrm{~A} \cdot \mathrm{aq}
\end{array} \rightarrow\right| \begin{gathered}
\mathrm{C}_{3} \mathrm{AH}_{6} \\
\mathrm{~A} \cdot \mathrm{aq}
\end{gathered}
$$

The absence of $\mathrm{C}_{2} \mathrm{AH}_{8}$ as well as $\mathrm{C}_{3} \mathrm{AH}_{6}$ hydrates in the investigated specimens can be explained by the fact that the CMC polymer forms a colloidal solution in the system the particles of which surround the $\mathrm{CA}$ and initially $\mathrm{CAH}_{10}$ formed particles, thus eliminating further hydratation. This process is assisted by the presence of a limited amount of water in the mixture and sufficiently fast aluminate cement hardening and curing.

The presence of $\mathrm{CaCO}_{3}$ (calcite also vaterite) in the samples can be explained in our opinion by the following processes:

1) $\mathrm{CA}+4 \mathrm{H}_{2} \mathrm{O}(\mathrm{s})=\mathrm{Ca}(\mathrm{OH})_{2}(\mathrm{t})+\mathrm{AH}_{3}$.

Our calculations show that the hydrolysis process Gibbs energy value $\Delta \mathrm{G}_{298}^{0}=-0,184 \mathrm{kcal}$; this means that the reaction is possible, although on a small scale,

2) $\mathrm{Ca}(\mathrm{OH})_{2}+\mathrm{CO}_{2}=\mathrm{CaCO}_{3}$.

$\mathrm{Ca}(\mathrm{OH})_{2}$ solution $\mathrm{pH}$ calculations were preformed to verify that the $\mathrm{CaCO}_{3}$ present in the specimen was formed from $\mathrm{Ca}(\mathrm{OH})_{2}$ according to the latter equation which is thermodynamically very close to chemical equi-

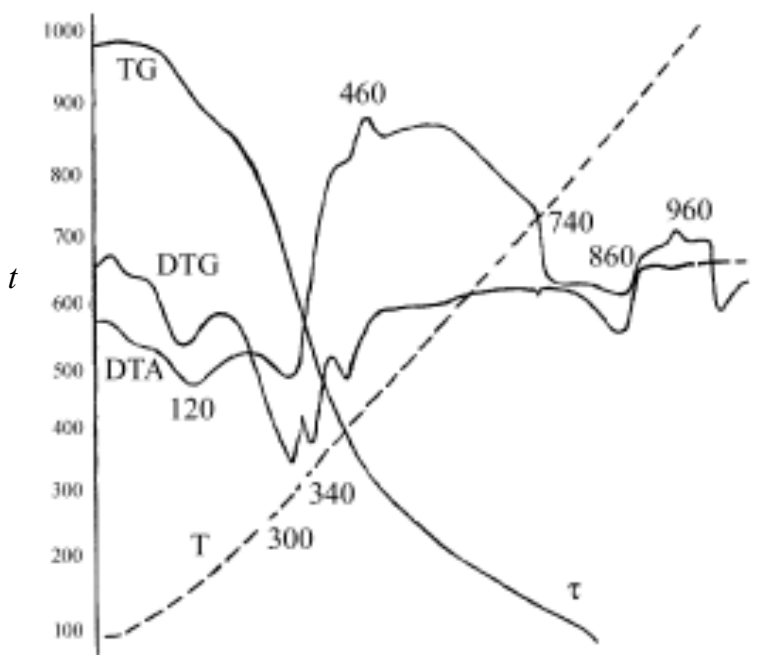

Fig 3. Derivatogram of mineral particles present in a specimen containing aluminate cement G-70, boon and PVA. Temperature curve $(\mathrm{T})-10 \% \mathrm{~min}$, mass change curve (TG) $-200 \mathrm{mg}$, heat change curve (DTA) - $250 \eta \mathrm{m}$, mass change rate curve (DTG) - $500 \eta \mathrm{m}$

librium. The following $\mathrm{Ca}(\mathrm{OH})_{2}$ solubility multiple given in the handbook was used for calculations.

$$
\mathrm{L}=\left[\mathrm{Ca}^{2+}\right]\left[\mathrm{OH}^{-}\right]^{2}=3,1 \cdot 10^{-5} \text {. }
$$

In the case of the equation

$$
\begin{aligned}
& \mathrm{Ca}(\mathrm{OH})_{2}(\mathrm{k}) \stackrel{\text { aq }}{\Leftrightarrow} \mathrm{Ca}^{2+}(\mathrm{t})+2 \mathrm{OH}^{-}(\mathrm{t}) \text { we get: } \\
& \mathrm{L}=\left[\mathrm{Ca}^{2+}\right]\left[\mathrm{OH}^{-}\right]^{2}=3,1 \cdot 10^{-5} ;\left[\mathrm{OH}^{-}\right]=0,5\left[\mathrm{Ca}^{2+}\right] ; \\
& \mathrm{L}=0,25\left[\mathrm{Ca}^{2+}\right]^{3}=3,1 \cdot 10^{-5} ;\left[\mathrm{Ca}^{2+}\right]=0,05 ;
\end{aligned}
$$

$\left[\mathrm{OH}^{-}\right]=0,025 \mathrm{M}$;

$\mathrm{pOH}=1,6 ; \mathrm{pH}=12,4$.

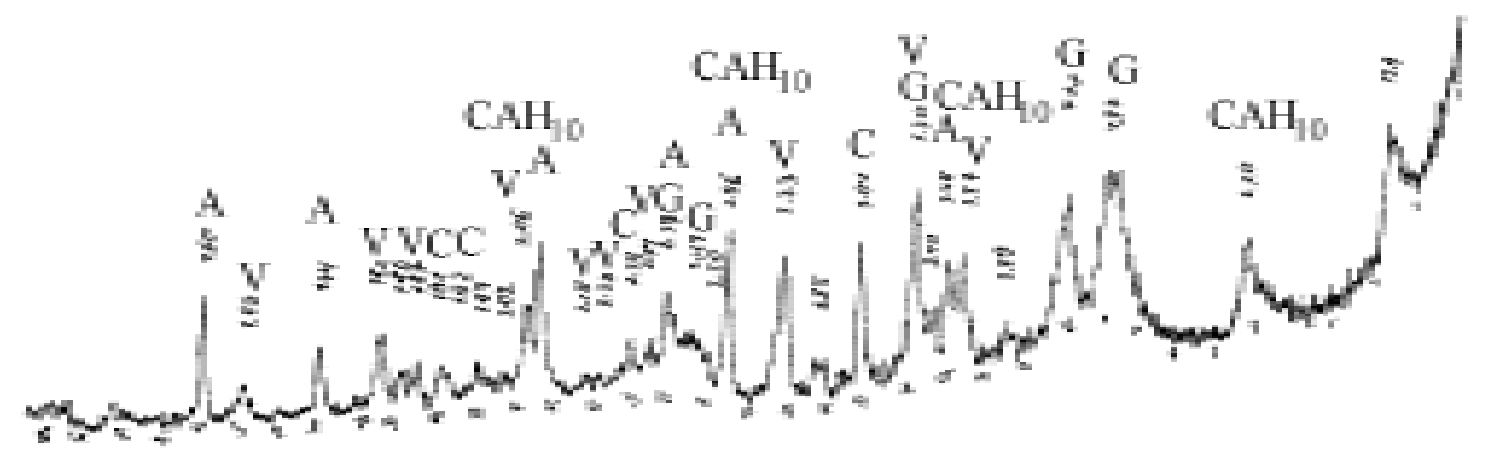

Fig 4. X-ray-gram of mineral particles present in a specimen containing aluminate cement, boon and PVA. Type of X-ray apparatus-DRON-2, anode-Co, filter-Fe. $\mathrm{CAH}_{10}-\mathrm{CaO} \cdot \mathrm{Al}_{2} \mathrm{O}_{3} \cdot 10 \mathrm{H}_{2} \mathrm{O} ; \mathrm{G}$ - gibbsite $\mathrm{Al}_{2} \mathrm{O}_{3} \cdot 3 \mathrm{H}_{2} \mathrm{O} ; \mathrm{A}-$ corundum $\alpha-\mathrm{Al}_{2} \mathrm{O}_{3} ; \mathrm{C}-$ calcite $\mathrm{CaCO}_{3} ; \mathrm{V}-$ vaterite $\gamma-\mathrm{CaCO}_{3}$ 
$\mathrm{pH}$-metric experiments were conducted with all the cements used. The following $\mathrm{pH}$ values were obtained for cement dispersion: in the case of aluminate cement $40 \mathrm{pH}=11,18$, for aluminate cement $70-\mathrm{pH}=10,58$ and for anhydrite cement $-\mathrm{pH}=9,49$.

This means that the described $\mathrm{CaCO}_{3}$ formation mechanism in the specimens is reliable.

The presence of $\alpha-\mathrm{Al}_{2} \mathrm{O}_{3}$ in the investigated samples can be explained in two ways: 1) $\mathrm{AH}_{3}$ formed during insignificant $\mathrm{CA}$ hydrolysis decomposes to $\mathrm{Al}_{2} \mathrm{O}_{3}$ and water during sample drying, 2) the presence of corundum admixtures in the aluminate cement.

\subsection{Retention of specimen form}

Experiments show that the form retention of hardened and dried samples in ambient air of a typical composition (50\% of cement, $45 \%$ filler and $5 \%$ of polymer binder-based on dry solids) depends on its composition (Figs 5, 6):

- Anhydrite cement binds boon better than chaff, while aluminate cement binds both evenly well.

- Vinyl acetate binders (PVA, Vinnap), irrespective of the type of cement used, binds cellulose fiber fillers better than cellulose binders (CMC, Walocel, MC).
The composition of steadfast samples is shown in the diagram (Fig 7 - a combination of aluminate cement 70 - polymer binders-chaff).

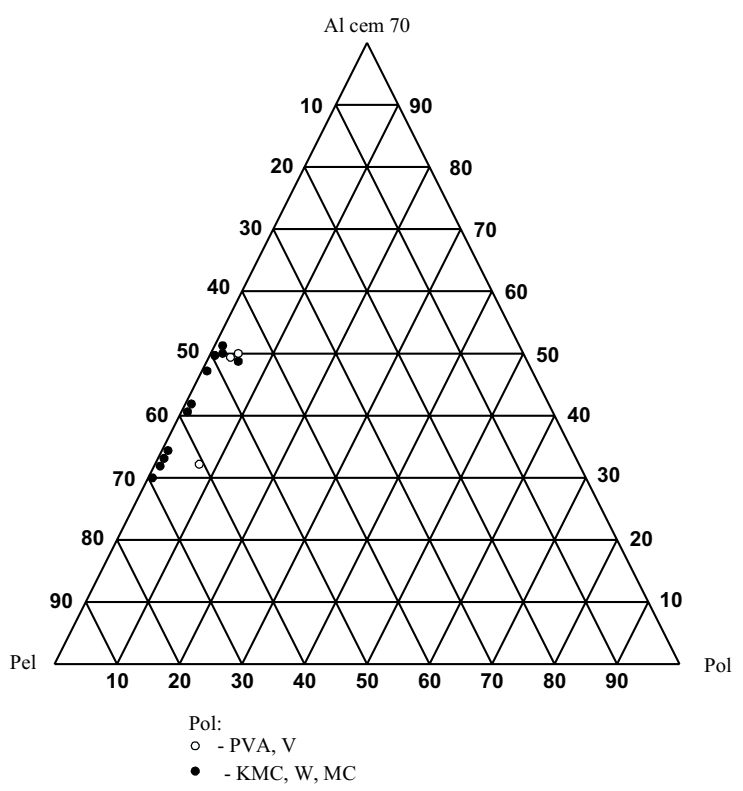

Fig 7. Triangular diagram for the composition of heat insulation composites made from aluminate cement 70 , polymeric binder and chaff

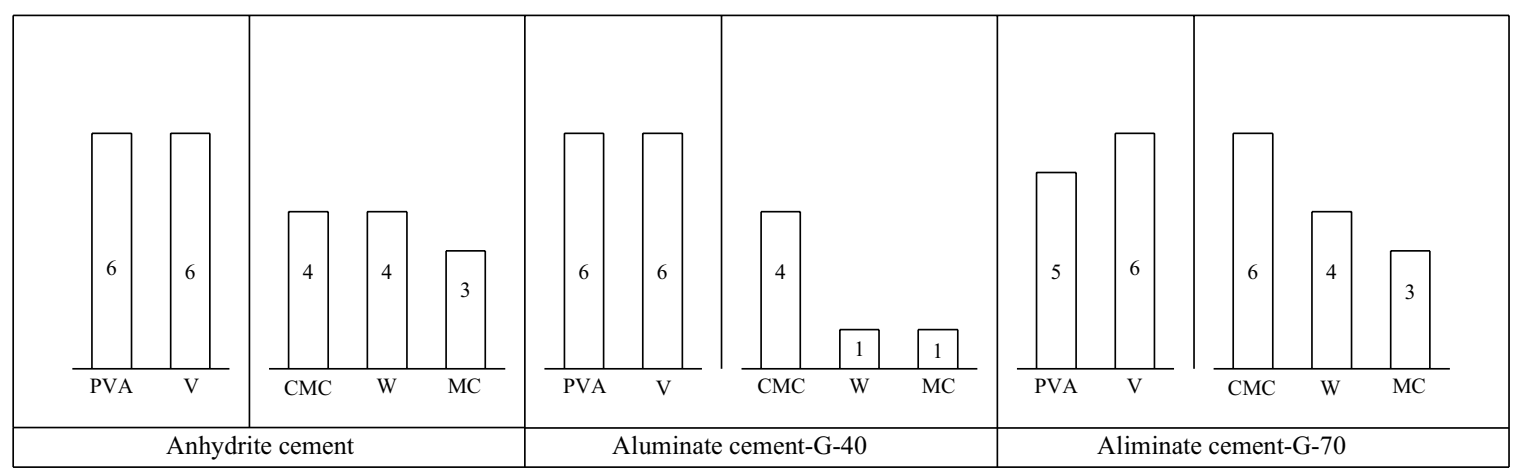

Fig 5. Influence of inorganic and polymer binder composition on the form steadfastness of a freshly formed and conditioned for 7 days specimen with standard composition (figures show the number of steadfast samples)

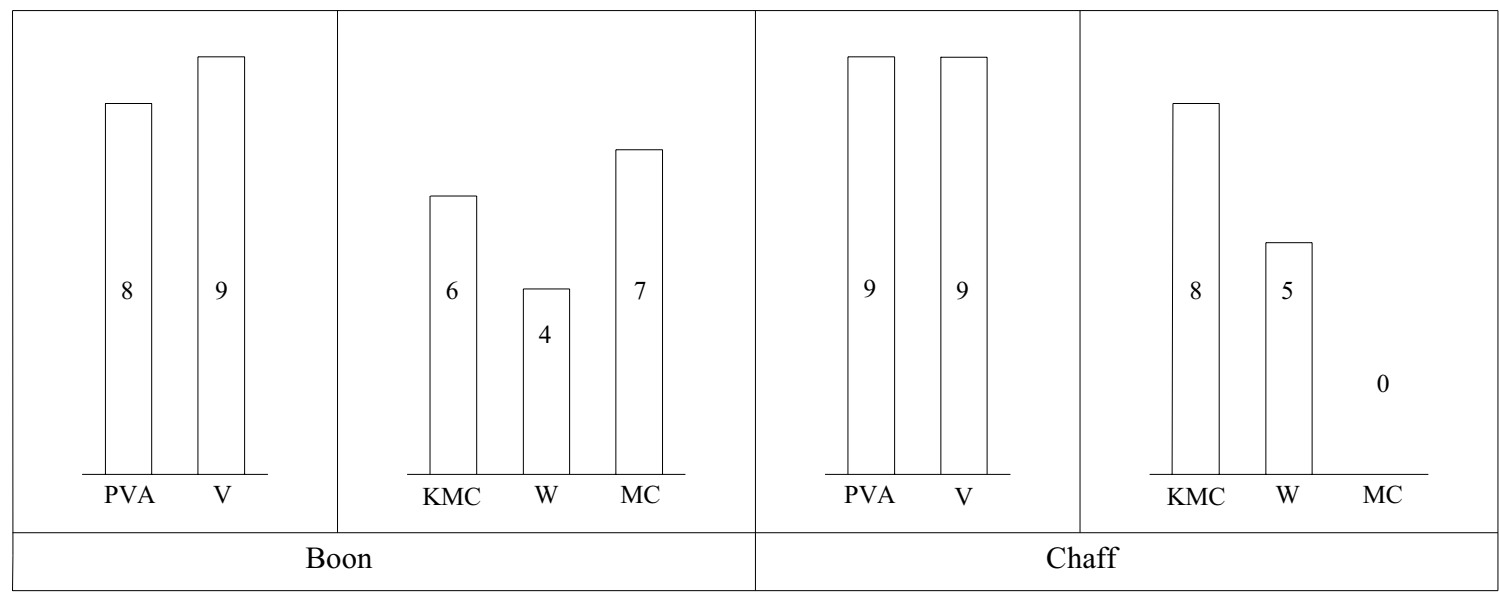

Fig 6. Influence of polymer binder and cellulose fiber filler composition on the form steadfastness of a freshly formed and conditioned for 7 days specimen with standard composition (figures show the number of steadfast samples) 


\subsection{Optimal compositions}

The most efficient compositions obtained in the investigation are given below (Table).

The tests have shown that the relationship between the mass of all the three inorganic binders and fillers is about one. Thus, in making mixes to produce heat insulating materials with the use of anhydrite or aluminate cement 70, equal amounts (by weight) of inorganic binder and cellulose fibre filler may be taken to facilitate the process. It is particularly suitable for manufacture in rural localities. In the case of aluminate cement 40 the amount of the latter should be 1,1-1,3 times the quantity of cellulose fibre filler.

\subsection{Composite density}

The composite density $\rho,\left(\mathrm{kg} / \mathrm{m}^{3}\right)$ depends on the amount of cement present in it according to a parabolic relationship (the case of Fig 8 with anhydrite cement and boon bound with CMC $4 \%$ dispersion).

According to the classification currently used in the EU states, the compositions obtained may be referred to as structural heat insulating materials $\left(\rho=(<500-600) \mathrm{kg} / \mathrm{m}^{3}, \lambda>0,2 \mathrm{~W} / \mathrm{m} \cdot \mathrm{K}\right)$.

The relationship - "density - cement quantity" in a composition containing anhydrite cement may be expressed in the following way:

$$
\rho=\rho_{\text {min }}+\Delta \rho\left(\mathrm{An}-\mathrm{An}_{\min }\right)^{2}, \mathrm{~kg} / \mathrm{m}^{3},
$$

where: $\rho_{\min }-$ minimal $\rho$ value determined from the diagram; $\Delta \rho$ - empirical $\rho$ increase ratio, $\mathrm{kg} / \mathrm{m}^{3} ; \mathrm{An}-$ anhydrite cement part, $\%$, in a composite; $\mathrm{An}_{\text {min }}$ - cement part, $\%$, in a composite, at minimal $\rho$ value.

The minimum referring to the dependence of the composite density on the amount of cement (about $30 \%$ ) in it found on the curves may be accounted for the following fact. When a composition is cement-free or having a small proportion of it, the polymer binder takes over the cement function, closely connecting the par-

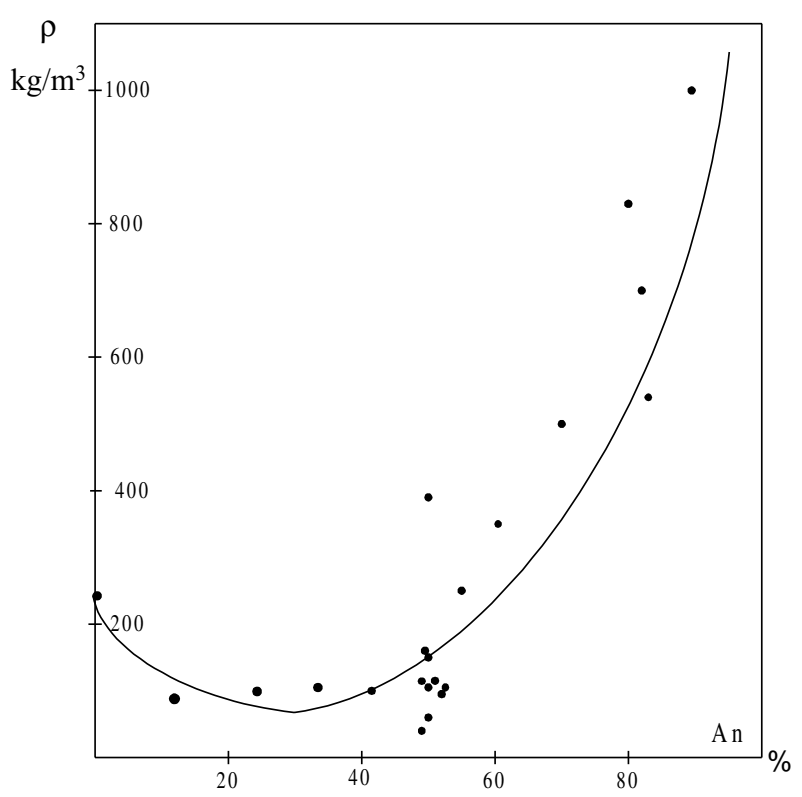

Fig 8. Dependence of the density $\left(\rho, \mathrm{kg} / \mathrm{m}^{3}\right)$ of heatinsulating composites containing anhydrite cement (An) and boon binder with $4 \%$ of CMC dispersion on the amount of cement present, An, \%

ticles of the filler. It results in a composite with a density higher than that of a material containing about $30 \%$ of cement. If the amount of cement is increased, the influence of its mass on composite density also increases, according to a parabolic relationship.

\subsection{Composite mechanical strength}

The composite flexural strength for $400 \mathrm{~kg} / \mathrm{m}^{3}$ and less density specimens with polymeric binder-CMC is in the $(0,6-1,3) \mathrm{MPa}$ range which is sufficient for hardening, transportation and assembly.

During compressive deformation samples with a density less than $400 \mathrm{~kg} / \mathrm{m}^{3}$ act not like brittle materials but are compressed. This composite property is very important during transportation and assembly work. This

Article composition percentage intervals (density not more than $400 \mathrm{~kg} / \mathrm{m}^{3}$ ) of inorganic binders, polymeric binders (dry state) and cellulose fiber fillers. Note: An - anhydrite cement, A 40 - aluminate cement 40, A 70 - aluminate cement 70, S - boon, P - chaff, PVA - polyvinyl acetate, V - Vinnap, CMC - carboxymethylcellulose, W - Walocel, MC - methylcellulose

\begin{tabular}{|c|c|c|c|}
\hline Composition & Inorganic binders & Polymeric binders & Cellulose fiber filler \\
\hline $\begin{array}{l}\text { An-S-PVA, V } \\
\text { An-S-KMC, W, MC }\end{array}$ & $\begin{array}{l}45-55 \\
42-60\end{array}$ & $\begin{array}{l}1-5 \\
1-5\end{array}$ & $\begin{array}{l}47-55 \\
40-55\end{array}$ \\
\hline $\begin{array}{l}\text { An-P-PVA, V } \\
\text { An-P-KMC, W, MC }\end{array}$ & $\begin{array}{l}35-55 \\
30-55 \\
\end{array}$ & $\begin{array}{c}2-8 \\
0,2-0,5\end{array}$ & $\begin{array}{l}45-60 \\
45-65 \\
\end{array}$ \\
\hline $\begin{array}{l}\text { A 40-S-PVA, V } \\
\text { A 40-S-KMC, W, MC }\end{array}$ & $\begin{array}{c}\text { absent } \\
50-60 \\
\end{array}$ & $\begin{array}{l}\text { absent } \\
\sim 5\end{array}$ & $\begin{array}{c}\text { absent } \\
40-45\end{array}$ \\
\hline $\begin{array}{l}\text { A 40-P-PVA, V } \\
\text { A 40-P-KMC, W, MC }\end{array}$ & $\begin{array}{l}45-55 \\
50-60 \\
\end{array}$ & $\begin{array}{l}5 \\
5-6 \\
\end{array}$ & $\begin{array}{l}40-50 \\
40-45 \\
\end{array}$ \\
\hline $\begin{array}{l}\text { A 70-S-PVA, V } \\
\text { A 70-S-KMC, W, MC }\end{array}$ & $\begin{array}{l}35-50 \\
35-55\end{array}$ & $\begin{array}{l}5 \\
1-5\end{array}$ & $\begin{array}{l}45-60 \\
45-65\end{array}$ \\
\hline $\begin{array}{l}\text { A 70-P-PVA, V } \\
\text { A 70-P-KMC, W, MC }\end{array}$ & $\begin{array}{l}30-50 \\
30-55\end{array}$ & $\begin{array}{l}5-8 \\
0,5-1\end{array}$ & $\begin{array}{l}45-60 \\
45-70\end{array}$ \\
\hline
\end{tabular}


feature can be explained by a isotropic composite structure in which the cellulose fiber filler is connected by polymeric patches which preform the function of a framework (Fig 9).

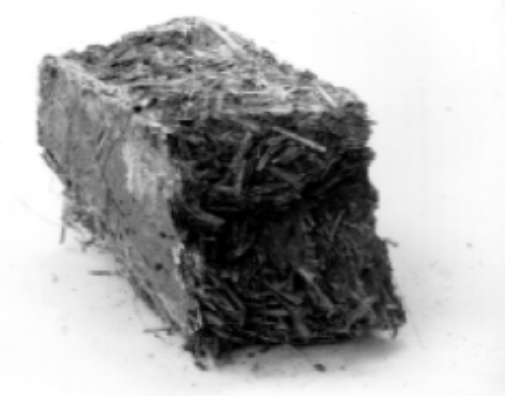

Fig 9. Fractured composite specimen containing $70 \%$ of aluminate cement $40,20 \%$ of boon and $10 \%$ of CMC (dry solids)

\subsection{Composite thermal conductivity}

To assess the heat insulating properties of anhydrite and aluminate containing lightweight walling materials, their $\lambda$ values had to be found. The samples of the composition found in the central areas of triangular diagrams were chosen for testing. These are the following composites:

1) A composite containing $50 \%$ of anhydrite cement, $45 \%$ of boon and $5 \%$ of CMC (dry solids) with $\rho=225 \mathrm{~kg} / \mathrm{m}^{3}$.

2) A composite containing $50 \%$ of aluminate cement $-70,45 \%$ of boon and $5 \%$ of PVA (dry solids) with $\rho=119 \mathrm{~kg} / \mathrm{m}^{3}$.

As a result, the following $\lambda$ values were obtained: 1) for anhydrite composite -

$$
\lambda=0,063 \pm 0,01 \mathrm{~W} / \mathrm{m} \cdot \mathrm{K},\left(\rho=225 \mathrm{~kg} / \mathrm{m}^{3}\right) \text {; }
$$

2) for aluminate composite -

$$
\lambda=0,12 \pm 0,01 \mathrm{~W} / \mathrm{m} \cdot \mathrm{K},\left(\rho=119 \mathrm{~kg} / \mathrm{m}^{3}\right) .
$$

Thus, the anhydrite and aluminate compositions investigated may be used in manufacturing lightweight walling and theat-insulating materials. The compositions may be obtained by using the triangular diagrams presented in this work.

\subsection{Composite heat resistance and costs calculations}

The obtained thermal insulation calculations were compared with heat losses $Q$ which arise when a typical building with a two-silicate-brick wide wall and a $2 \mathrm{~cm}$ plaster layer is heated from October to April at a mean outdoor and inside temperature of $0,7{ }^{\circ} \mathrm{C}$ and $20^{\circ} \mathrm{C}$, respectively. The following results were obtained:

- for a non-insulated wall $-Q=18152 \mathrm{kWh}$;
- for walls of the same building insulated for warmth keeping with an $8 \mathrm{~cm}$-thick composite $(\lambda=0,08 \mathrm{~W} / \mathrm{m} \cdot \mathrm{K})$ layer covered with gypsum-cardboard $-Q=14135 \mathrm{kWh}$;

- for the same case with a $10 \mathrm{~cm}$-thick composite layer $-Q=10645 \mathrm{kWh}$.

The relationship between the heat loss value $Q_{2}$ (for a wall after insulating materials were applied) and heat loss value $Q_{1}$ (for a wall before to insulation was installed) was as follows, \%:

$$
\left(Q_{2} / Q_{1}\right) 100=(10645 / 18152) 100=58,6 \% .
$$

In fact, the above value is slightly higher than the efficiency factor of the boiler $n=0,7$ used for heating a building, while the heat losses of the heating system $N$ reach $13 \%$, ie $N=13$. Taking into account the above considerations, we find that the insulation of walls of a building for warmth-keeping can save the following amount of heat:

$$
\begin{aligned}
& \Delta Q_{\text {fakt }}=\Delta Q / \eta(1-0,01 \mathrm{~N})=7507 / 0,7(1-0,01 \cdot 13)= \\
& 12327 \mathrm{kWh} \text { or } 44,4 \mathrm{GJ} .
\end{aligned}
$$

In rural localities fuel oil is burned in heating boilers, while coal or wood are used for firing furnaces. When fuel oil is used in urban boiler rooms, its cost is by about $30 \%$ higher. Since the average cost of fuel oil in the world is about $73 \$$ per ton (recalculated as equivalent fuel), 1,5 ton of fuel oil will cost $526 \mathrm{Lt}$.

Thus, by winter-proofing a house of $100 \mathrm{~m}^{2}$ with its walls insulated only with the suggested thermal insulating materials, more than $520 \mathrm{Lt}$ a year may be saved (in the period of heating including October-April, ie for 7 months or 219 days).

Assuming an average cost of $1 \mathrm{~m}^{2}$ of insulating materials to be $10 \mathrm{Lt}$, the insulation of $170 \mathrm{~m}^{2}$ wall area will cost $1700 \mathrm{Lt}$.

Therefore, than average repay time of building winter-proofing with insulating materials will make $1700: 526=3,23$, ie the renovation of building walls will repay less than in 4 years

Calculations show that the composite's role is especially revealed when a wall is insulated according to the following scheme $\left(\rho-\right.$ layer density, $\mathrm{kg} / \mathrm{m}^{3} ; \delta$ - layer thickness, $\mathrm{m} ; \lambda$ - specific thermal conduction coefficient, $\mathrm{W} / \mathrm{m} \cdot \mathrm{K})$ :

- decorative brick masonry $(\rho=1600 ; \delta=0,12$; $\lambda=0,64)$

- composite $(\rho=750 ; \delta=0,125 ; \lambda=0,11)$

- holey clay brick masonry $(\rho=1600 ; \delta=0,12$; $\lambda=0,64)$

- $\operatorname{stucco}(\rho=1700 ; \delta=0,02 ; \lambda=0,87)$

In this case the composite thermal resistance makes up for $65,5 \%$ of the total wall thermal resistance. 


\subsection{Principled technological scheme for producing lightweight walling and heat-insulating materials}

Fig 10 shows a principal anhydrite and aluminate lightweight wall and heat-insulating material production principled scheme is proposed.

Raw material hoppers are filled with an inorganic binder (1), a cellulose fiber filler (2) and a dry polymeric binder (3). Water is held in the tank (4). All the reservoirs are equipped with batchmeters (10).

The polymeric binder dispersion is prepared by mixing it in a separate reservoir (5) equipped with a mixing device (6). The required amount of dispersion is then dispensed through a batch meter (10).

After that the required amount of cement and filler material is transported to a mixing reactor (7). All the dry raw materials are mixed in the mixer (6). After that the required amount of polymer dispersion is introduced into the reactor. All the components are well mixed in the mixer (6).

Then the prepared raw material mixture is transported to pressforms where they are formed by a press (8). After the required hardening time the obtained prefabricated articles are forwarded to a warehouse (9).

\section{Conclusions}

1. Lightweight walling and heat-insulating composites were developed based on inorganic binders (anhydrite cement, aluminate 40 and aluminate 70 cements); polymeric binders-vinyl acetate (PVA, Vinnap); cellulose binders (CMC, Walocel, MC); cellulose fiber fillers (chaff, boon) and special additives (antiseptics, flameretarders, water-proefers, etc).

2. The article steadfastness during assembly is dependant on the following indices: a minimal amount of anhydrite cement in various compositions should be $\geq 30-45 \%$; a minimal amount of aluminate cement-40 $\geq 45-50 \%$; a minimal amount of aluminate cement-70 $\geq 30-35 \%$; a minimal amount of vinyl acetate polymer binder in various compositions $-\geq 0,5-$ $5,0 \%$; minimal cellulose fiber filler amount in various compositions $-\geq 40-47 \%$.

3. Vinyl acetate binders in combination with all cements bind cellulose fiber fillers (chaff and boon) better than cellulose binders; anhydrite cement binds boon better than chaff, while aluminate cement binds both with equal success.

4. When the amount of cement used in composi-

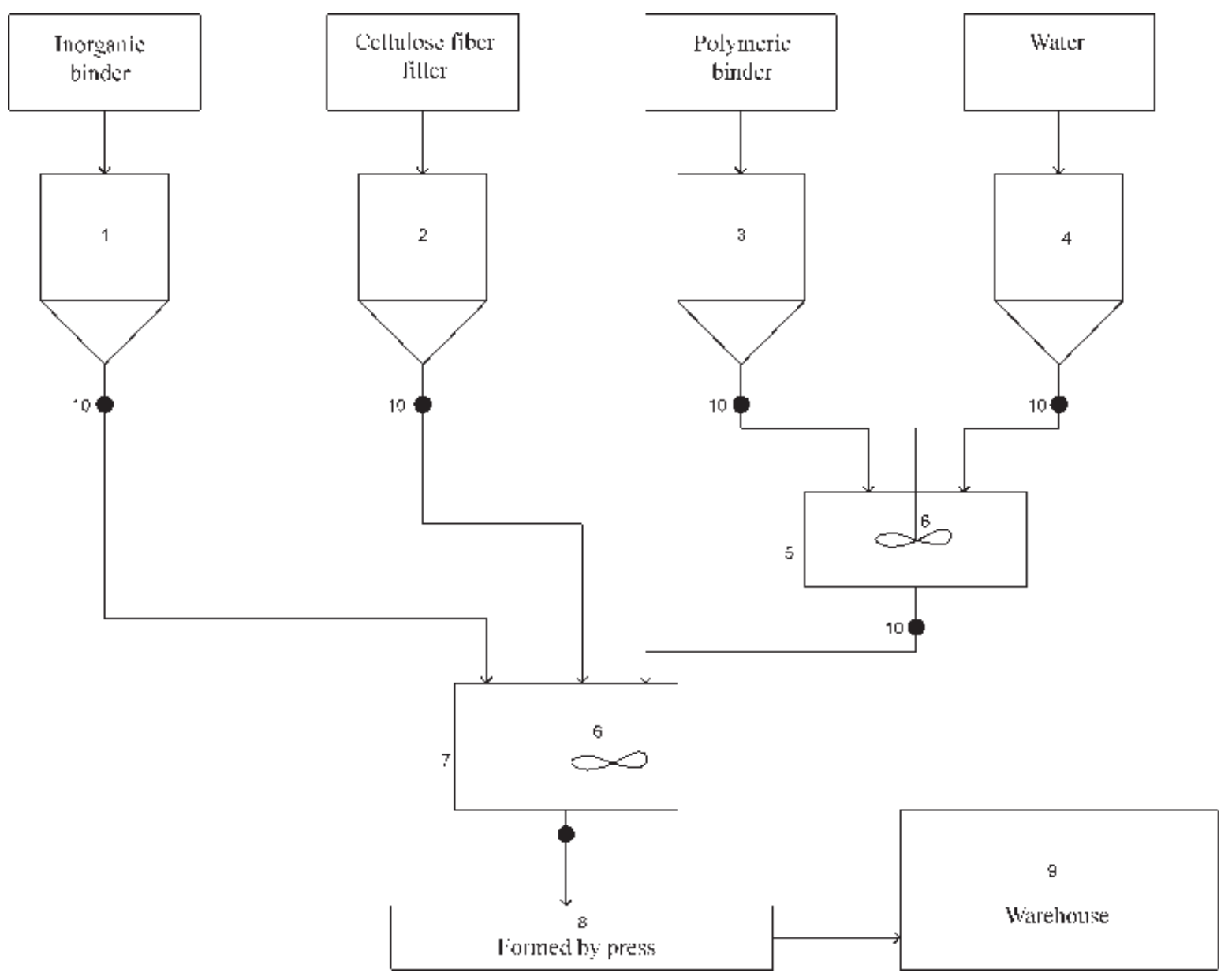

Fig 10. Principled technological scheme for manufacturing lightweight walling and heat-insulating materials containing anhydrite and aluminate. 1-3 - raw material hoppers; 4 - a water reservoir; 5 - a reservoir for polymeric binder dispersion; 6 a dispersion mixer; 7 - a mixing reactor; 8 - a press; 9 - a warehouse; 10 - a material dispenser 
tions does not exceed $50-60 \%$ the specimen density is lower than $400 \mathrm{~kg} / \mathrm{m}^{3}$ which is correlatively inversely proportional to the specific thermal conductivity coefficient. According to this index, the developed compositions belong to the lightweight heat-insulating material class. The specimen density $\rho$ for all cements depends on the amount of cement present in a sample, \% according to the approximate parabolic dependence.

5. The specimen flexural strength is in the range of $0,6-1,3 \mathrm{MPa}$ when the specimen density is lower than $400 \mathrm{~kg} / \mathrm{m}^{3}$ and CMC is used as a polymeric binder. This is enough for article transportation and assembly. Such specimens deform under pressure in a different way than fragile materials - they are compressed. This property of the material is of special importance in transportation and assembly.

6. The composite article thermal conductivity coefficient is about $0,06 \mathrm{~W} / \mathrm{m} \cdot \mathrm{K}$ for specimens with a density lower than $400 \mathrm{~kg} / \mathrm{m}^{3}$. The use of the developed heat-insulating slabs for insulating buildings can substantially increase the wall thermal resistance. For example, a $170 \mathrm{~m}^{2}$ building built by using a two-silicate-brick wall and a $2 \mathrm{~cm}$ plaster layer could have heat losses of about 18 thousand $\mathrm{kWh}$ during a 7-month cold season, and if $8 \mathrm{~cm}$ thick composite slabs were used, the heat losses could be lowered to 14 thousand $\mathrm{kWh}$, if $10 \mathrm{~cm}-$ $10,6 \mathrm{kWh}$. That is why the use of developed composite slabs for insulation of buildings (6 variations are possible) can save as much as 1,5 tons of conventional fuel. It follows that the building wall insulation costs could be paid off in less than 4 years.

7. The use of agricultural by-products for heat- insulating material production would not allow them to decay and form $\mathrm{CH}_{4}$ and $\mathrm{CO}_{2}$ gases which could take part in lowering the atmospheres greenhouse effect.

\section{References}

1. Kazragis, A.; Nickus, I.; Gailius, A. Construction Material Production Technology Using Organic Fillers. In: Proceedings of $4^{\text {th }}$ International conference „Modern Building Materials, Structures and Techniques“. Vilnius, Technika, 1995, p. 234-238 (in Lithuanian).

2. Kazragis, A.; Gailius, A.; Nickus, I. Heat Insulating Materials Made from Local Raw Materials. Construction and Architecture (Statyba ir architektūra), No 4, 1996, p. 1516 (in Lithuanian).

3. Kazragis, A.; Milčiūnienè V.; Kulinič, H.; Gailius, A.; Nickus, I. Use of Organic Production Waste for Manufacturing Construction Materials Investigation. Environmental Engineering (Aplinkos inžinerija), No 2(6), 1996, p. 18-24 (in Lithuanian).

4. Kazragis, A.; Kulinič, H.; Gailius, A.; Nickus, I. Straw bricks Containing Carboxymethylcellulose in its Compositions. In: Proceedings of International Conference Lithuanian Science and Industry "Silicate technology". Kaunas: Technologija, 1999, p. 142-147 (in Lithuanian).

5. Kazragis, A.; Gailius, A.; Kulinič, H. Influence of composition structure on the properties of building products with agricultural elements. Investigation. Environmental Engineering (Aplinkos inžinerija), No 4, 2000, p. 223-227 (in Lithuanian).

6. Kazragis, A.; Gailius, A.; Juknevičiūtè, A. Thermal and Acoustical Insulating Materials Containing Mineral and Polymeric Binders with Celluloses Fillers. Materials Science (Medžiagotyra), Vol 8, No 2, Kaunas, 2002, p. 193-195 (in Lithuanian).

7. Kazragis, A.; Gailius, A.; Tamulaitienè, B.; Kulinič, H. Utilization of straw and reed in building product fabrication. Investigation. Environmental Engineering (Aplinkas inžinerija), Vol 10, No 2, 1996, p. 77-83 (in Lithuanian).

8. Fischer, A. K.; Bullen, F.; Beal, D. The durability of cellulose fibre reinforced concrete pipes in sewage application. Cement and Concrete Research, Vol 31(4), 2001, p. 543-553.

9. Blankenhorn, P. R.; Blankenhorn, B. D.; Silsbee, M. R.; DiCola, M. Effects of fiber surface treatments on mechanical properties of wood fiber-cement composites. Cement and Concrete Research, Vol 31(7), 2001, p. 1049-1055.

10. Biricik, H.; Akoz, F.; Turker, F. and Berktay, I. Resistance to magnesium sulfate and sodium sulfate attack of mortars containing wheat straw ash. Cement and Concrete Research, Vol 30(8), 2000, p. 1189-1197.

11. Blankenhorn, P. R.; Silsbee, M. R.; Blankenhorn, B. D.; DiCola, M. and Kessler, K. Temperature and moisture effects on selected properties of wood fiber-cement composites. Cement and Concrete Research, Vol 29(5) 1999, p. 737-741.

12. Savastano, H.; Warden, Jr.; P. G and Coutts, R. S. P. Ground iron blast furnace slag as a matrix for cellulose-cement materials. Cement and Concrete Composites, Vol 23(4-5), 2001, p. 389-397.

13. Qijun, Yu; Sawayama, K.; Sugita, S.; Shoya, M. and Isojima, Y. The reaction between rice huck ash and $\mathrm{Ca}(\mathrm{OH})_{2}$ solution and the nature of its product. Cement and Concrete Research, Vol 29 (1), 1999, p. 37-43.

14. Cisse, I. K. and Laquerbe, M. Mechanical characterisation of filler sandcretes with rise huck ash additions. Cement and Concrete Research, Vol 30(1), 2000, p. 13-18.

15. Savastano, H.; Warden, Jr.; P. G. and Coutts, R. S. P. Brazilian waste as fibres as reinforcement for cement-based composites. Cement and Concrete Composites, Vol 22(5), 2000, p. 379-384.

16. Singh, N. B.; Singh, V. D.; Rai Sarita and Chaturvedi Shivani. Effect of lignosulfonate, calcium chloride and their mixture on the hydration of RHA-blended portland cement. Cement and Concrete Research, Vol 32(3), 2002, p. 387-392.

17. Sebok, T. Relationships between the properties of ligninsulphonates and parameters of modified samples with cement binders. Cement and Concrete Research, Vol 30(4), 2000, p. 511-515.

18. Coutts, R. S. P. and Ni, Y. Autoclaved Bamboo Pulp Fibre Reinforced cement. Cement and Concrete Composites, Vol 17(2), 1995, p. 99-106.

19. Bložè, V. Non-fired bricks made of local raw materials. Construction and Architecture, No 9, 1994, p. 20 (in Lithuanian). 


\section{SPALIU IR PELU UTILIZAVIMAS GAMINANT LENGVAS SIENINES MEDŽIAGAS}

\section{A. Kazragis, A. Juknevičiūtè, A. Gailius, E. Zalieckienė}

S antrauka

Gauti lengvi sieniniai bei šilumos izoliaciniai kompozitai, kuriuos sudaro neorganiniai rišikliai (anhidritinis cementas, aliuminatinis cementas-40 ir aliuminatinis cementas-70), polimeriniai rišikliai (vinilacetatiniai - PVA, Vinnap); celiulioziniai (KMC, Walocell, MC)), celiulioziniai plaušiniai užpildai (pelai, spaliai).

Dirbiniu patvarumą transportuojant bei montuojant lemia tam tikri rodikliai. Minimalus ịvairių medžiagu kiekis kompozicijose turi būti: anhidritinio cemento $-\geq(30-45) \%$; aliuminatinio cemento-40 - $\geq(45-50) \%$; aliuminatinio cemento-70 $\geq(30-35) \%$; vinilacetatinių polimerinių rišiklių - $\geq(1-5) \%$; celiuliozinių rišiklių $-\geq(0,5-5,0) \%$; celiuliozinių plaušinių užpildų - $\geq(40-47) \%$.

Bandinių tankis, kai naudotų cementų kiekis kompozicijose neviršija (50-60) \%, yra mažesnis negu $400 \mathrm{~kg} / \mathrm{m}^{3}$. Pagal ši rodikli sukurti kompozitai priskiriami lengvuju šilumos izoliacinių medžiagų klasei. Bandinių tankis, esant skirtingiems cementams, priklauso nuo cemento kiekio bandinyje.

Bandiniu lenkiamasis stipris, kai nustatant naudojami bandiniai, kurių tankis neviršija $400 \mathrm{~kg} / \mathrm{m}^{3}$, o kaip polimerinis rišiklis - $\mathrm{KMC}$, yra 0,6-1,3 $\mathrm{MPa}$.

Bandinių, kurių tankis mažesnis nei $400 \mathrm{~kg} / \mathrm{m}^{3}$, savitasis šilumos laidžio koeficientas esti apie $0,06 \mathrm{~W} / \mathrm{m} \cdot \mathrm{K}$.

Raktažodžiai: utilizavimas, lengvos sieninès medžiagos, šilumos izoliacija, spaliai, pelai, neorganiniai rišikliai, polimeriniai rišikliai.

\section{УТИЛИЗИРОВАНИЕ КОСТРЫ И МЯКИНЫ В ПРОИЗВОДСТВЕ ЛЕГКИХ СТЕНОВЫХ МАТЕРИАЛОВ}

А. Казрагис, А. Юкнявичюте, А. Гайлюс, Е. Залецкене

Р е $з$ ю м е

Получены легкие стеновые и теплоизоляционные композиты, состоящие из ангидридного (АН) или алюминатного (АЛ) цемента, винилацетатных (ВА) или целлюлозных (ЦЛ) полимерных вяжущих и волокнистых целлюлозных заполнителей (костры, мякины).

Устойчивость изделий при транспортировке и монтаже обусловливается следующими показателями: содержание АН $\geq(30-45) \%$, АЛ $\geq(30-50) \%$, ВА $\geq(1-5) \%$, ЦЛ $\geq(0,5-$ $5,0) \%$, костры или мякины $\geq(40-47) \%$. Вяжущие типа ВА в случае обоих видов цемента связывают заполнители лучше, чем вяжущие типа ЦЛ; АН связывает костру лучше, чем мякину; АЛ одинаково успешно связывает оба заполнителя.

Плотность композита $\rho$ при содержании цемента в

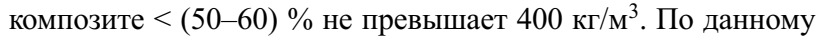
показателю полученные композиты относятся к классу легких теплоизоляционных материалов. Значение $\rho$ зависит от содержания цемента в композите по параболической закономерности.

Прочность композитов при изгибе для образцов $\rho \leq 400$ кг $/ \mathrm{M}^{3}$ в случае применения КМС составляет $(0,6-$ $1,3)$ МПа. Такие образцы при сжатии деформируются как эластичные материалы и подвергаются прессованию, что особенно важно при их транспортировке и монтаже.

Коэффициент теплопроводности образцов, обладающих плотностью менее чем $400 \mathrm{\kappa} / \mathrm{M}^{3}$, составляет около $0,06 \mathrm{BT} / \mathrm{M} \cdot К$. При использовании для отепления стен дома площадью в $170 \mathrm{~m}^{2}$ плит из таких композитов толщиной в 10 см потери тепла за сезон уменьшаются на 10,6 тыс. кВт час.

Ключевые слова: утилизация, легкие стеновые материалы, теплоизоляция, костра, мякина, неорганические вяжущие, полимерные вяжущие. 